The Effective Delivery of Franchisor Services: A Comparison of U.S. and German Support Practices for Franchisees

\author{
Marko Grünhagen \\ Eastern Illinois University \\ School of Business \\ 4012 Lumpkin Hall \\ Charleston, IL 61920 \\ +1 217 581-6906 (Phone) \\ +1 217 581-6247 (Fax) \\ mgrunhagen@eiu.edu
}

\author{
Robin B. DiPietro \\ University of Nebraska \\ Department of Nutrition and Health Sciences \\ 202G Ruth Leverton Hall \\ Lincoln, NE 68583 \\ +1 402-472-3875 (Phone) \\ +1 402-472-4427 (Fax) \\ rdipietro2@unl.edu \\ Robert E. Stassen \\ University of Arkansas \\ Department of Marketing \& Logistics \\ 302 Walton College of Business \\ Fayetteville, AR 72701 \\ +1 479 575-6155 (Phone) \\ +1 479 575-8407 (Fax) \\ bstassen@walton.uark.edu \\ Lorelle Frazer \\ Griffith Business School \\ Griffith University, Logan campus \\ University Drive \\ Meadowbrook Qld 4131 \\ Australia \\ +61 733821179 (Phone) \\ +61 733821190 (Fax) \\ l.frazer@griffith.edu.au
}




\title{
The Effective Delivery of Franchisor Services: A Comparison of U.S. and German Support Practices for Franchisees
}

\begin{abstract}
Conventional wisdom suggests that more services offered by franchisors should lead to fewer complaints from franchisees, and that franchisees ought to be better off with additional support provided. We set out to differentiate those services that are truly effective and that are perceived as beneficial by franchisees, from those that may have little effect or may even be perceived as counterproductive. Our survey targeted franchisors in the U.S. and in Germany, comparing the most mature franchise market globally to one that is relatively young. System disruption was found to be dependent on the maturity of the market, as little differentiation is provided in the very mature U.S. market, but considerable differentiation exists in the younger German market. Also, the size of the system matters, as bigger systems typically provide more services. Finally, different types of services have varying levels of effectiveness in the less mature franchise market of Germany.
\end{abstract}

Keywords: Services, franchisee, franchisor, franchising, franchise, disruption, failure, comparison, Germany, international 


\section{The Effective Delivery of Franchisor Services: A Comparison of U.S. and German Support Practices for Franchisees}

\section{Introduction}

Franchising as a method of conducting business is so pervasive that one out of every twelve retail businesses in the U.S. is a franchised business, and more than eight million people are employed in these operations. According to the International Franchise Association, franchising accounts for more than 40 percent of all retail sales and totals more than a trillion dollars in revenue annually (International Franchise Association 2004).

Only recently has research attention in franchising turned to reasons for franchise failure. Failures or “disruptions” in franchised systems have been defined by Frazer (2001) as legal disputes and franchised outlet conversions to some other form of ownership (whether company owned, converted to another independent operation, or closed altogether). Reasons for system disruption that have been identified include the size and age of the franchise system (Frazer 2001, Frazer and Winzar 2005). It has also been shown that franchisees are more likely to leave their system if the associated start-up cost is relatively low (Frazer and Winzar 2005). On the other hand, failure among franchisees declines with prior industry experience, the requirement for franchisees to actively manage their outlets, exclusive territories, and lower royalty rates (Michael and Combs 2007), leading the authors to suggest that strengthening and protecting franchisees' interests in an effort to take care of unit owners “is usually in franchisors' best interest” (Michael and Combs 2007, p. 22). However, no evidence has been found thus far that a lack of franchisor support causes franchise system disruption (Frazer 2001).

Accordingly, in an attempt to take a more differentiated look at specific services offered by franchisors to their franchisees, this study investigates differences in the delivery and 
effectiveness of services in a cross-country comparison. Our survey targeted franchisors in the U.S. and in Germany in an attempt to compare the most mature franchise market globally to one that is relatively young, using survey items previously employed in Australia (Frazer 2001). Insights gained from this study provide important directions for franchisors in their evaluation of the portfolio of services they offer to their franchisees. Conventional wisdom in the franchise industry appears to extol the virtue that more services offered by franchisors should lead to fewer complaints from franchisees, and that franchisees ought to be better off with additional support provided. Differentiating those types of services that are truly effective and that are perceived as beneficial by franchisees, from those that may have little effect or may even be perceived as counterproductive allows franchisors to "weed out” unnecessary support efforts. Such a cleansing process may aid franchisors in their efforts to provide true "value added" to their franchise owners, while offering cost savings to their bottom lines. Further, the comparison of a mature to a much younger franchise market may provide guidelines for franchisors in their global expansion efforts with regards to the suitability of services offered in relation to the maturity of the marketplace they are entering.

\section{Background Literature}

\section{Franchising}

Franchising is commonly considered a hybrid between autonomy and dependence. Franchisees of various types exist, often distinguished by the size of their operation, and the modalities of the contractual agreement with the franchisor (Kaufmann and Dant 1996). They typically pay an entry fee as well as recurring royalties and advertising fees to the franchisor. In return, franchise owners receive the right to use the trademark or even the entire business format 
as well as a host of services provided by the franchisor, often including staff training, centralized booking services and hotlines, market analysis assistance, software support, and the like.

The literature has developed two primary arguments for the existence of a franchised business, resource scarcity and agency theory. Resource scarcity theory considers three elements that franchisors often lack at the outset: (1) financial capital, (2) human capital, and (3) market knowledge (Oxenfeldt \& Kelly 1968/69). Encountering difficulties in raising capital and developing managerial talent, during the early stages of a franchise system's existence, franchisors recruit franchisees that will invest the money needed and undertake a portion of the subsequent risk. The constraints of money, employee labor and management are reduced considerably for franchisors if they can find franchisees that are responsible for building and staffing units so that the franchisors can focus on the development of the system and the brand (Carney and Gedajlovic 1991; Caves and Murphy 1976; Oxenfeldt and Kelly 1968/69; Shane 1996). The notion of “ownership redirection” (Brown 1998; Dant, Paswan and Kaufmann 1996; Kaufmann and Dant 1996; Lafontaine 1992; Lafontaine and Kaufmann 1994; Rubin 1978) suggests that, while franchising often appears as the necessary means of expansion during early stages of the franchise life cycle due to the earlier described capital constraints, at later life cycle stages the franchisor develops an inherent interest in buying back franchised units and reverting them to company-owned units, since diversified investors in the system would presumably require a lesser return than relatively undiversified franchise owners. Indeed, Lafontaine and Shaw (2005) showed that franchisors over time appear to develop a target portfolio, i.e., a specific balanced mix of franchised and corporate units.

Relatedly, agency theory (Eisenhardt 1989; Jensen and Meckling 1976) provides justification for franchising from the perspective that franchisees are less apt to shirk their 
responsibility because they have a stake in the business. Their incentives are directly linked to their performance, which is typically not the case with managers of businesses. When the business is owned by a franchisee, the owner's livelihood is directly linked to the performance of the unit, so that the franchisor's costly need for monitoring individual units is greatly reduced (Fama and Jensen 1983; Norton 1988; Rubin 1978).

Recently, agency theory and resource scarcity have been integrated by Castrogiovanni, Combs and Justis (2006), indicating that a paradigm shift from the resource scarcity to the agency view might occur over time. While resource constraint concerns prevail during the early stages of the franchise system's life cycle, after an initial expansion, monitoring and the related costs appear to move into the franchisor's focus and agency motives start guiding the continued use of franchising, rather than reverting units back to the franchisor.

From the franchisee's perspective, the benefits of franchising in general lie in the proven concept and system. The availability of franchisor support services as a strong motivator for individuals to be attracted to franchising as a business concept has been noted elsewhere (Dant 1995; Dant and Peterson 1990). Aspiring franchisees appear to be attracted to the perceived security that they associate with the franchisor backing them while also being dependent on their success with the overall system. Clearly, as a franchise system expands, and an individual franchisee's importance as part of such a system begins to be reduced, at the outset simply by the number of new franchisee entrants, services provided by the franchisor could be expected to take on greater importance in connecting the franchisee with the franchisor. 


\section{Franchise System Failure and Disruption}

Holmberg and Morgan (2005) suggest that the distinction between what constitutes franchise system failure and franchisee failure is complex, yet significant. Frazer and Winzar (2005) note that it may be difficult to determine whether a franchise system fails, as the company itself may cease to exist, or franchisees might sell back their units to the company or to other franchisees. In other words, the failure of an entire system may well be linked to an exceedingly high turnover rate among its franchised units. However, no consistent definition of franchise system failure has been agreed upon in the literature. This ambiguity, paired with the plethora of causalities that may contribute to the outright failure of entire franchise systems, may well be the reason that has prompted researchers to develop alternative concepts. In a study conducted by Frazer (2001) of Australian franchisors, two primary causes of "disruption” to franchise systems were examined, lack of franchisor support and stage of the franchise life cycle. "Disruptions" to franchise systems are defined by Frazer (2001) as legal disputes between franchisee and franchisor, and franchised outlet conversions to some other form of ownership (whether company owned, converted to another independent operation, or closed altogether). Reasons for system disruption that have been identified include the size and age of the franchise system (Frazer 2001, Frazer and Winzar 2005). As systems mature and expand, substantial disputes between franchisor and franchisee may either cause the franchisor to take over franchised units, or may provide reason for a franchisee to break away from the system and begin to operate as an independent business. It has also been shown that franchisees are more likely to leave their system when the associated start-up cost is relatively low (Frazer and Winzar 2005), i.e., in cases where there are few requirements to invest in transaction specific assets. A recent study (Michael and Combs 2007) investigated primarily failures among franchisees. Franchisee failure was 
shown to decline with prior industry experience, the requirement for franchisees to actively manage their outlets, exclusive territories, and lower royalty rates (Michael and Combs 2007). Yet, no evidence has been found thus far that a lack of franchisor support for franchisees causes franchise system disruption (Frazer 2001).

\section{Purpose and Context of the Study}

Since many potential franchisees get into the business at least in part in response to the support provided by franchisors, it would seem that the services provided would help to create a perception of greater security for franchisees when they enter into the franchising relationship. Anecdotal evidence suggests that franchisees frequently demand more support services than they currently receive. Franchisors on the other hand often appear to believe that the more services they provide, the better they address franchisee demands and preempt complaints, and the more successful their franchisees will be, i.e., the less disruption the system will encounter.

The purpose of this study was twofold. First, we wanted to explore empirically the prevalence and the predictability of the different services offered to franchisees in both a mature franchise market (U.S.) and a franchise market that is less developed (Germany). The German franchise market has gone through two stages of development. Until the fall of the Berlin Wall in 1989, the West German market had slowly developed as a lagging mirror image of franchising in the U.S. A major push in the development of franchising occurred with McDonald's entry into Germany in the early 1970s, which was followed by other fast-food and restaurant systems as well as a slow expansion of hotel systems into the German market. After 1989, East Germany became a sort of "Wild East" for global franchise expansion, and it took a type of pioneering position for those systems that were looking at expansion into other Central and Eastern 
European countries. Yet, the German franchise market with only about 850 existing franchise systems (German Franchise Association 2007) would still be considered a relatively young franchise market with a balanced mix of foreign and indigenous franchise systems.

Our second goal was to investigate the effectiveness of the services offered by franchisors in Germany and in the U.S. to their franchisees. In other words, we wanted to examine the relationship of individual services to system disruption, as measured in the Frazer (2001) study by outlets closed or converted.

\section{Methodology}

This study was conducted using questions from a survey that developed and tested a model of franchise system disruption in Australia (Frazer 2001). The survey consisted of ten items and included questions about the year that franchising was started by the organization, the number of units (both franchised and company owned), the types of support provided by the franchisor to franchisees in the system, the number of legal disputes that the company has had with franchisees, and the number of units that have changed in status in the three years prior to the survey administration.

The U.S. sample was collected randomly from franchisors listed in The Franchise Handbook (2005). The survey was posted on a website, and respondents were asked via e-mail to link to the website to access and complete the questionnaire. A total of 539 franchisors were sent e-mails, and 2 additional follow-up emails were sent in accordance with Dillman (2000). There were 99 useable surveys returned for a response rate of 18.4 percent.

In Germany, the survey was conducted in two waves. First, the questionnaire was handed out at the German Franchise Forum, an annual meeting of franchisors and franchise executives. 
In addition, the German Franchise Association agreed to send out an e-mail to all of its members requesting their participation in completing the survey. Two follow up emails were then sent out to request participation. A total of 111 franchisors returned useable surveys.

\section{Findings}

\section{Services Provided to Franchisees}

Table 1 provides a comparison of the German and U.S. samples in terms of the number of services provided to the franchisees by the systems. The German sample was composed of younger (average years franchising was 10+ years versus 15+ year in U.S.), smaller systems offering fewer services. In contrast, the U.S. sample had 48 systems offering 11 or more services to the franchisees. An additional difference in the samples is that years franchising had a stronger association with the number of franchised units in the German sample $(r=.55)$ than was found in the older U.S. sample $(r=.20)$, indicating that the German systems were in a period of more pronounced growth than the U.S. sample.

Table 2 shows the number and proportion of systems providing the individual fourteen services by the two groups of franchise systems. The table illustrates the similarities and significant differences in the services provided by the two countries' franchisors in (1) the frequency that a service is provided and (2) the predictability, or reproducibility, of its occurrence as part of a wider offering of services. The two countries differ significantly (significant t-values for differences in proportions) in their respective proportions of services in five specific areas: staff training, software ordering, telephone assistance, franchisee council and point-of-sale assistance, with U.S. franchisors offering the listed services generally at a higher frequency than the German franchisors, except for telephone assistance. 
The reproducibility is included in the analysis to illustrate the "predictability" of an individual service within the broader offering of services to franchisees. It provides an indication of the pattern of responses produced across responses, such that if you knew that a franchisor offered $n$ different services, one could predict them by selecting the $n$ most frequently offered. Reproducibility was higher (82 \%) for the U.S. sample than for the German sample (74 \%), indicating less duplication (or more differentiation) among the German franchisors. Differences in individual items were shown, for example, a telephone assistance "hotline" had a significantly higher frequency in the German sample, but with roughly the same predictability was not a differentiating factor.

\section{Effects on Franchise System Disruption}

To identify those services with the most potential to minimize system disruption, the proportion of the systems' outlets either closed or converted were compared between those systems providing the service versus those which did not. We would expect those systems providing a service to experience lower disruption, with a highly significant difference identifying the services of the most interest.

Due to the significant differences of services offered between the two samples and more predictable pattern of offerings within the U.S. sample, we chose a disaggregated approach to examining the effects of these individual services on system disruption. Two standardized measures of disruption were created by dividing the number of units that were closed and/or converted to company-owned units by the number of franchisee units and the total number of units in the system. In addition to disruption, the denominators of these measures are also of interest in that they will indicate the importance of system size in determining if a service is 
provided to its franchisees. Due the pattern of predictability among the 14 services shown in Table 1, larger systems could be expected to offer more services.

Table 3 provides the pooled results for the U.S. and German samples, comparing the means for the two measures of system size and the two measures of system disruption for each of the fourteen services. The table includes the standard deviations and identifies comparisons with significant differences between the groups. This is of interest when an assumption of equality of sample variance is violated in the comparison when the difference in means is large in magnitude. Across all 14 services, mean system size was larger for those systems providing the service to its franchisees, and significant differences are shown in at least one measure of size for nine of the comparisons. Means in disruption as a proportion of the number of franchised outlets were significantly different in two instances, insurance offered and Internet services, although disruption was significantly higher (.069 vs. .030) for those systems providing Internet services. In summary, the results in the table show there is a predictable association between the services offered and the size of the franchise system, with only a single instance where the service has been shown to significantly reduce system disruption.

Table 4 provides comparisons of system size in franchise units and disruption as a proportion of franchised units for the German and U.S. samples, illustrating markedly different results. The U.S. results are similar to the results provided in Table 3, with no significant difference shown in disruption due to the provision of a service, with the provision of these services more associated with larger franchise systems.

The German sample shows less association of system size with the provision of service, but highly significant differences associated with six of the fourteen services. Counter to expectations, significantly higher levels of disruption are shown in systems providing three 
services than those that do not (newsletters, Internet services, and field visits). In contrast, franchise councils, insurance and franchise training were associated with lower system disruption. Importantly, of these six, only in the case of Internet services it is associated with system size.

\section{Discussion and Implications}

This paper has examined the services provided to franchisees, illustrating the differences that can be shown within samples and the association of these services with system disruption. Clearly, there are strong, predictable associations between the number of services that can be provided to franchisees and a system's size. Bigger systems typically offer more services to their franchisees, as could be expected. The effectiveness of the services offered in addressing disruption, however, is very unclear in the U.S., and varies in Germany. While larger systems provide a franchise council, newsletters, market analysis, and other areas of support, there is not a single comparison between systems where one of the services is shown to be associated with a reduction in system disruption. U.S. franchisors may choose to reconsider their broad assortment of services, and examine carefully those which are neither seen to be expected by new franchisees nor demonstrate effectiveness within their own systems. This could help franchisors to be more effective with regards to the services they choose to provide to franchisees.

The German results illustrate the benefit from examining services in a relatively younger market where franchisors can experiment with approaches expected in a more mature franchise market, such as the U.S., and evaluate the results. In general, German franchise systems offer fewer services than their U.S. counterparts, yet they also show much more variation. In other words, differentiating support services across systems in Germany provides an opportunity for 
franchisors to create a competitive advantage in the franchisee recruiting and retention market. Three specific services offered by German franchisors merit additional discussion. Whereas newsletters are a highly predictable service used in significantly larger U.S. systems, they have no association with system size in Germany, and are more likely found in systems experiencing disruption. Internet services are more associated with larger systems in Germany, whereas in the U.S. they are independent of system size, and are also more likely found in systems experiencing disruption. An explanation for both of these services to be associated with greater (rather than lesser) levels of disruption may lie in the perception they may create with franchisees. While the franchisor's intent may rest in creating greater transparency to motivate franchisees, unit owners may actually find the ability to compare their own results to those of other franchisees in the system, and particularly to "top performers" quite de-motivating. For example, all locations within a franchise system are approved by the franchisor with the understanding that they will provide an expected, or minimal, level of volume at a given level of competition, and across heterogeneous set of locations, a high degree of location potential will exist. Drawing attention to the fact that their fellow franchisees may have superior locations or face less competition cannot inspire increased output. This notion also finds support in the literature on social comparison theory (Festinger 1954) that suggests that individuals may compare themselves with others who share a social status, but with whom they have no direct interaction (Merton 1957). As a consequence of such self referencing, individuals may become dissatisfied with themselves, and demotivated with regards to their tasks (Higgins 1987; Wood 1989). Also, some franchisees may perceive the use of an intranet that was originally designed to improve within-system communication as a cost-cutting measure by the franchisor, and thus, it may be viewed negatively (Watson 2006). Such intranet use may also encourage the franchisor to request more 
information from franchisees, which could raise concerns that may threaten the autonomy of individual owners (Watson 2006).

While the data illustrate that field visits may be regarded as a franchisor service to the franchisee, the German results suggest that this may be more likely a response to disruption, as those systems with higher disruption are requiring the implementation of a regular field visit policy. Alternatively, franchisees may perceive field visits not as supportive, but rather as a way of being monitored, and respond negatively as a consequence.

Staff training, software ordering, telephone assistance, Point of Sale (POS), and franchise council were five areas with significant differences in predictability between the U.S. and German samples, where in all five instances the pattern of predictability was higher in the U.S. In all instances in Germany, these five had slightly, though not highly significant, associations with reduced disruption. This would suggest that German systems seeking to offer more assistance to franchisees focus on these areas as they appear more effective than others.

\section{Limitations}

Limitations to this study must not be ignored. This examination surveyed franchisors regarding the services they provide and the disruptions in their systems based on the closing or ownership change of their units. However, we did not investigate franchisees regarding the types of services they receive, or the quality of these service offerings. Neither did we consider the resulting financial performance outcomes of provided services for the franchise owners. Future studies are encouraged to expand the approach taken here into a dyadic research design that incorporates matching pairs of franchisors and franchisees to investigate perceptions of services and their quality, as well as provide estimates on their salience regarding financial performance. 
We also did not provide specific definitions of the various services customarily offered by franchisors. While this approach leaves it to individual respondents to interpret their meanings, we felt that most of these services are relatively standardized across systems, thus leaving little need for specification. We do, however, recognize that there is room for refinement in subsequent investigations. For example, using the term field visit does not specify whether the actual visit is announced or rather a surprise “drop-in” that is not anticipated, and hence cannot be planned for. Similarly, the widespread existence of “plural systems”, i.e., companies in which franchised and corporate units coexist (Bradach and Eccles 1989, Cliquet 2000, Dant, Kaufmann and Paswan 1992), may actually lead to differential experiences with the types of services offered. Centralized booking, for example, may be considered a welcome support service by corporate hotel mangers, while franchisees of the same system may consider this offering as a measure that favors the company-owned units and "siphons" reservations away from franchisees.

\section{Conclusion}

In summary, conventional wisdom in the franchise industry suggests that more services offered by franchisors should lead to fewer complaints from franchisees, and that franchisees ought to be better off with additional support provided. We set out to differentiate those services that are truly effective and that are perceived as beneficial by franchisees, from those that may have little effect or may even be perceived as counterproductive. Identifying effective services may aid franchisors in their efforts to provide true "value added" to their franchise owners, while offering cost savings to their bottom lines. Further, the comparison of a mature (U.S.) to a much younger franchise market (Germany) offers guidelines for franchisors in their global expansion 
efforts regard appropriate support services offered in relation to the maturity of the marketplace they are entering.

We find that system disruption is clearly dependent on the maturity of the market, as not much differentiation of services is provided in the very mature U.S. market, but a good amount of differentiation exists in the relatively younger German market. Also, the size of the system that offers the services matters, as bigger systems typically (can) provide more services. Finally, different services have been shown to be more or less effective in the less mature franchise market of Germany. While offering staff training, software ordering, telephone assistance, Point of Sale (POS), and franchise councils was associated with less disruption to a system's functioning, the provision of services such as field visits and newsletters actually appears to lead to more rather than less disruption. We suggest that field visits may be perceived as more monitoring rather than as supportive, and newsletters may provide benchmarks ("our top performers in the system") that may be de-motivating rather than being seen as encouraging. As a recommendation for future investigations, more in-depth analysis into the typicality of certain offerings in particular industries needs to be conducted. Also, it appears vital to investigate franchisees' perceptions of services offered, as franchisees may not always understand the intention of the franchisor in offering certain services, and interpret them as intrusive rather than supportive. 
Table 1: Number of Services Provided by Franchise Systems

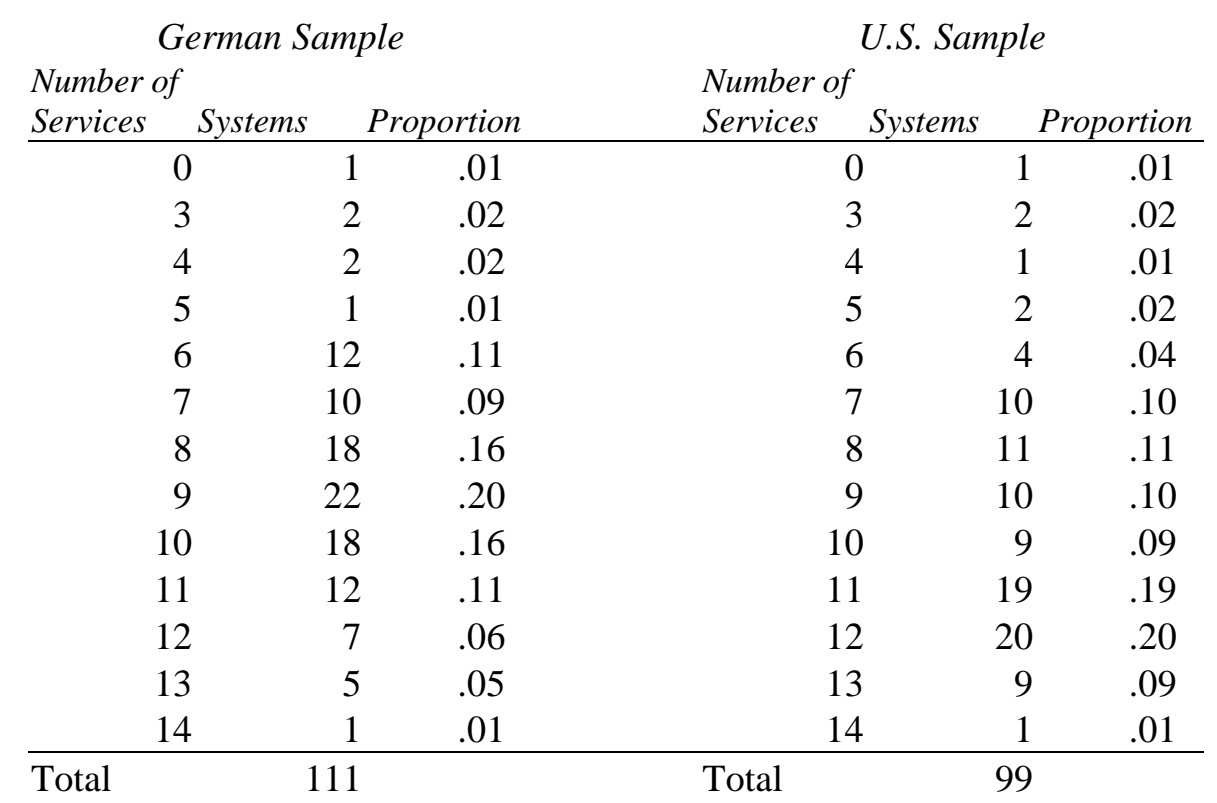


Table 2: Services Provided to Franchisees, U.S. and German Samples - Comparisons of Frequencies and Proportions

\begin{tabular}{|c|c|c|c|c|c|c|c|c|c|c|}
\hline & \multicolumn{4}{|c|}{ U.S. Sample, $n=99$} & \multicolumn{4}{|c|}{ German Sample, $n=111$} & \multicolumn{2}{|c|}{ Differences between Proportions } \\
\hline & \multicolumn{2}{|c|}{ Frequency } & \multicolumn{2}{|c|}{ Reproducibility } & \multicolumn{2}{|c|}{ Frequency } & \multicolumn{2}{|c|}{ Reproducibility } & \multirow{2}{*}{$\begin{array}{c}\text { Frequency } \\
t\end{array}$} & \multirow{2}{*}{$\begin{array}{c}\text { Reproducibility } \\
\text { t2 }\end{array}$} \\
\hline & $n$ & $p(\%)$ & $n_{r}$ & $p_{r}(\%)$ & $n$ & $p(\%)$ & $n_{r}$ & $p_{r}(\%)$ & & \\
\hline Fran Training & 92 & 93 & 88 & 96 & 97 & 88 & 90 & 93 & 1.18 & .85 \\
\hline Field Visits & 90 & 91 & 85 & 94 & 98 & 89 & 89 & 91 & .44 & .96 \\
\hline Internet Services & 86 & 87 & 81 & 94 & 91 & 83 & 80 & 88 & .84 & 1.48 \\
\hline Staff Training & 81 & 82 & 76 & 94 & 76 & 69 & 61 & 80 & $2.17^{\mathrm{b}}$ & $2.56^{\mathrm{b}}$ \\
\hline Newsletters & 85 & 86 & 77 & 91 & 97 & 88 & 87 & 90 & -.50 & .20 \\
\hline Software Ordering & 78 & 79 & 69 & 88 & 62 & 56 & 45 & 73 & $3.58^{\mathrm{a}}$ & $2.36^{\mathrm{b}}$ \\
\hline Telephone Assistance & 77 & 78 & 67 & 87 & 99 & 90 & 91 & 92 & $-2.41^{\mathrm{b}}$ & -1.04 \\
\hline National Conference & 80 & 81 & 69 & 86 & 81 & 74 & 61 & 75 & 1.24 & $1.78^{\mathrm{C}}$ \\
\hline Market Analysis & 63 & 64 & 54 & 86 & 80 & 73 & 65 & 81 & -1.41 & .72 \\
\hline Franchise Council & 73 & 74 & 59 & 81 & 56 & 51 & 37 & 66 & $3.51^{\mathrm{a}}$ & $1.88^{\mathrm{C}}$ \\
\hline POS & 62 & 63 & 49 & 79 & 41 & 37 & 24 & 59 & $3.78^{\mathrm{a}}$ & $2.21^{\mathrm{b}}$ \\
\hline Insurance Offered & 48 & 48 & 34 & 71 & 49 & 45 & 32 & 65 & .57 & .58 \\
\hline Centralized Booking & 23 & 23 & 12 & 52 & 26 & 24 & 12 & 46 & -.07 & .42 \\
\hline Other Support for Franchisees & 21 & 21 & 9 & 43 & 25 & 23 & 9 & 36 & -.26 & .47 \\
\hline Average & & 69 & & 82 & & 64 & & 74 & & \\
\hline
\end{tabular}

${ }^{\mathrm{a}}: \mathrm{p}<.01 ;{ }^{\mathrm{b}}: \mathrm{p}<.05 ;{ }^{\mathrm{c}}: \mathrm{p}<.10$ for significant differences in sample means and standard deviations. 
Table 3: Comparisons of Differing Measures of Size and System Disruption by Service Provided to Franchisees

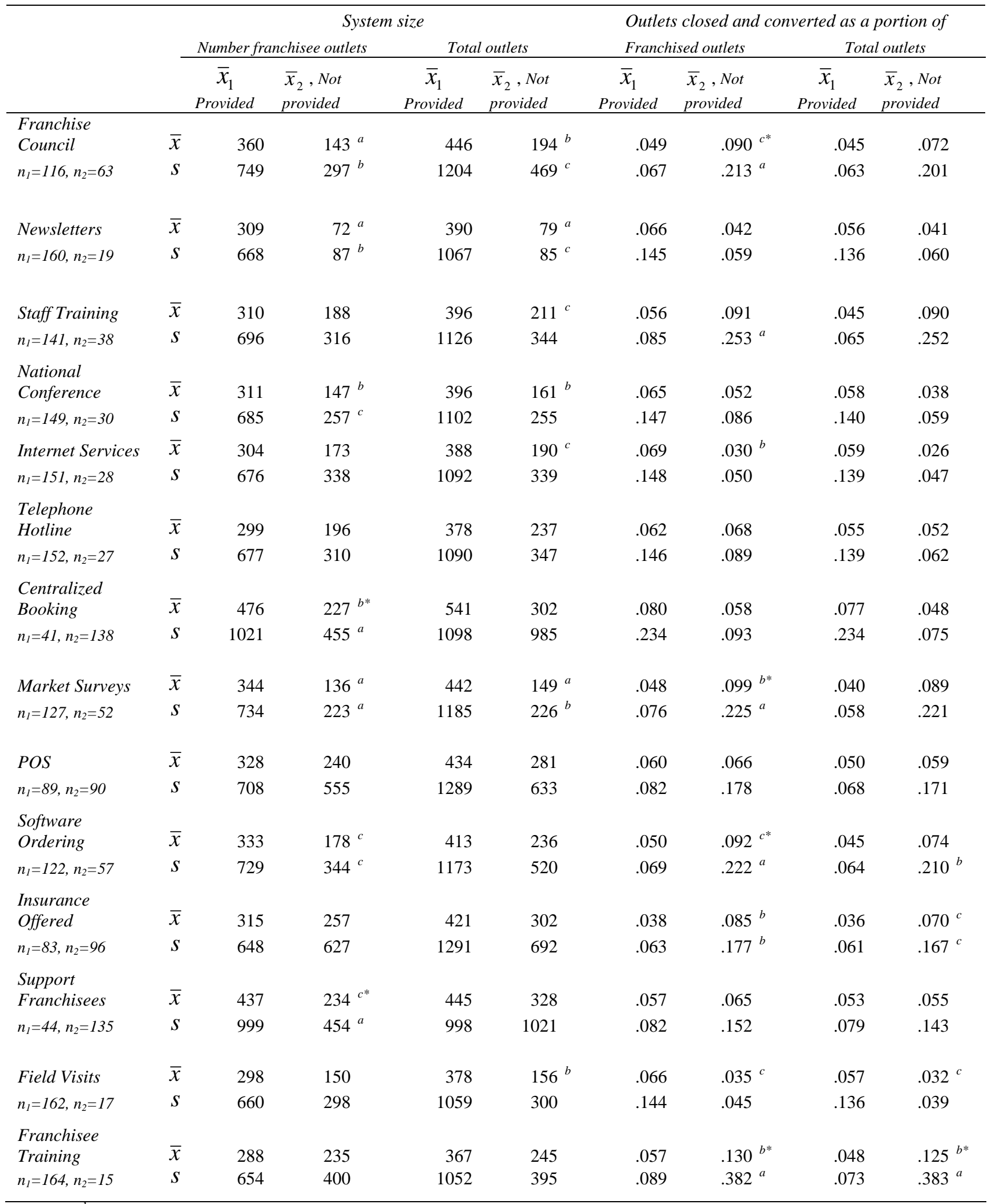

${ }^{\mathrm{a}}: \mathrm{p}<.01{ }^{\mathrm{b}}: \mathrm{p}<.05 ;{ }^{\mathrm{c}}: \mathrm{p}<.10$ for significant differences in sample means and standard deviations.

* denotes comparison with unequal sample standard deviations result in failure to reject hypothesis of equal means. 
Table 4: Sample Comparisons of Size and System Disruption by Service Provided to Franchisees

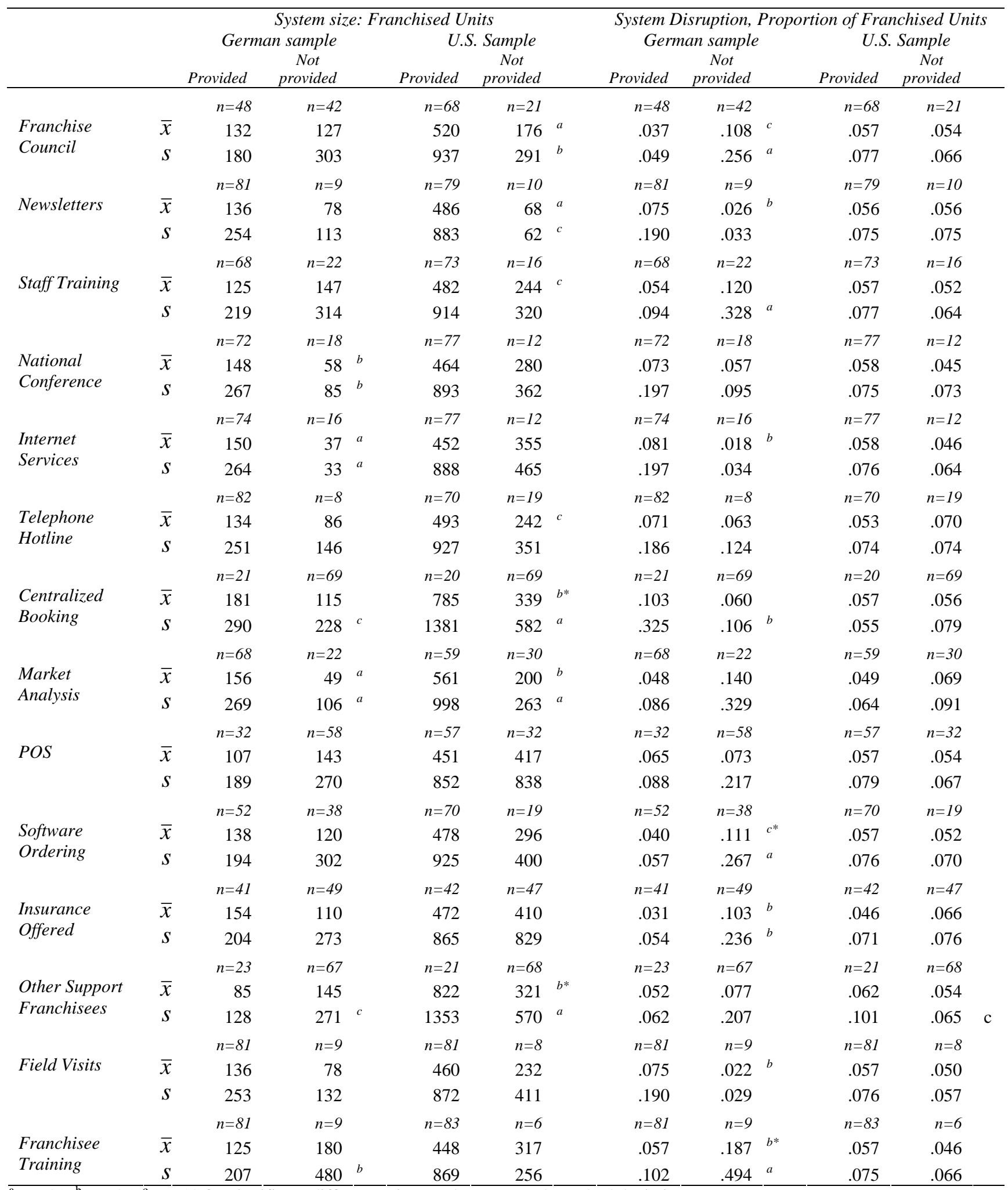

${ }^{\mathrm{a}}: \mathrm{p}<.01 ;{ }^{\mathrm{b}}: \mathrm{p}<.05 ;{ }^{\mathrm{c}}: \mathrm{p}<.10$ for significant differences in sample means and standard deviations.

* denotes comparison with unequal sample standard deviations result in failure to reject hypothesis of equal means. 


\section{References}

Bradach, J.L. and R.G. Eccles (1989). Price, Authority and Trust: From Ideal Types to Plural Forms. Annual Review of Sociology, 15, 97-118.

Brown, W. (1998). Transaction Costs, Corporate Hierarchies and the Theory of Franchising. Journal of Economic Behavior and Organization, 36, 319-329.

Carney, M. and E. Gedajlovic (1991). Vertical Integration in Franchise Systems: Agency Theory and Resource Explanations. Strategic Management Journal, 12, 607-629.

Castrogiovanni, G.J., J.G. Combs and R.T. Justis (2006). Shifting Imperatives: An Integrative View of Resource Scarcity and Agency Reasons for Franchising. Entrepreneurship Theory \& Practice, 30(1), 23-40.

Caves, R. E. and W. F. Murphy (1976). Franchising: Firms, Markets, and Intangible Assets. Southern Economic Journal, 42(April), 572-586.

Cliquet, G. (2000). Plural Forms in Sore Networks: A Model for Store Network Management. International Review of Retail, Distribution and Consumer Research, 10(4), 369-387.

Dant, R.P. (1995). Motivations for Franchising: Rhetoric versus Reality. International Small Business Journal, 14(1), 10-32. 
Dant, R.P., P.J. Kaufmann and A.K. Paswan (1992). Ownership Redirection in Franchised Channels. Journal of Public Policy and Marketing, 11(1), 33-44.

Dant, R.P., A.K. Paswan and P.J. Kaufmann (1996). What We Know About Ownership Redirection in Franchising: A Meta-Analysis. Journal of Retailing, 72, 429-444.

Dant, R.P. and A. Peterson (1990). Perceived Advantages of the Franchise Option from the Franchisee Perspective: Empirical Insights from a Service Franchise. Journal of Small Business Management, 28(July), 46-61.

Dillman, D. A. (2000). Mail and Internet Surveys: The Tailored Design Method (2 ${ }^{\text {nd }}$ ed.). New York, N.Y.: John Wiley Co.

Eisenhardt, K. (1989). Agency Theory: An Assessment and Review. Academy of Management Review, 14(1), 57-74.

Fama, E. and M. Jensen (1983). Agency Problems and Residual Claims. Journal of Law and Economics, 26, 327-349.

Festinger, L. (1954). A Theory of Social Comparison Processes. Human Relations, 7(May), 117-140.

Frazer, L. (2001). Causes of Disruption to Franchise Operations. Journal of Business Research, 54(3), 227-234. 
Frazer, L., and H. Winzar (2005). Exits and Expectations: Why Disappointed Franchisees Leave. Journal of Business Research, 58(11), 1534-1542.

German Franchise Association [Deutscher Franchise Verband e.V.] (2007). “Der Begriff “Franchising”. Retrieved from http://www.dfv-franchise.de/ September 10, 2007

Higgins, E.T. (1987). Self-Discrepancy: A Theory Relating Self and Affect. Psychological Review, 94(July), 319-340.

Holmberg, S.A., and K.B. Morgan (2005). Entrepreneurial Franchise Ventures: US and European Franchise Failure Strategic Perspectives and Empirical Investigation. Proceedings of the International Society of Franchising Conference, London, UK.

International Franchise Association (2004). How Widespread is Franchising? Retrieved from http://www.franchise.org/resourcectr/faq/q4.asp, July 5, 2004.

Jensen, M.C. and W.H. Meckling (1976). Theory of the Firm: Managerial Behavior, Agency Costs and Ownership Structure. Journal of Financial Economics, 3(4), 305-360.

Kaufmann, P.J. and R.P. Dant (1996). Multi-Unit Franchising: Growth and Management Issues. Journal of Business Venturing, 11(5), 343-358.

Lafontaine, F. (1992). Agency Theory and Franchising: Some Empirical Results. RAND Journal of Economics, 23(2), 263-283.

Effective Delivery of Franchisor Services3 of 25 
Lafontaine, F. and P.J. Kaufmann (1994). The Evolution of Ownership Patterns in Franchise Systems. Journal of Retailing, 70, 97-113.

Lafontaine, F and K.L. Shaw (2005). Targeting Managerial Control: Evidence from Franchising. RAND Journal of Economics, 36(1), 131-150.

Merton, R.K. (1957). Social Theory and Social Structure. Glencoe, IL: Free Press.

Michael, S.C. and J.G. Combs (2007). Entrepreneurial Failure: The Case of Franchisees. Journal of Small Business Management (forthcoming).

Norton, S.W. (1988). Franchising, Brand Name Capital, and the Entrepreneurial Capacity Problem. Strategic Management Journal, 9(Summer), 105-114.

Oxenfeldt, A.R. and A.O. Kelly (1968/69). Will Successful Franchise Systems Ultimately Become Wholly-Owned Chains? Journal of Retailing, 44(Winter), 69-83.

Rubin, P. (April, 1978). The Theory of the Firm and the Structure of the Franchise Contract. Journal of Law and Economics, 21, 223-233.

Shane, S. (1996). Hybrid Organizational Arrangements and Their Implications for Firm Growth and Survival: A Study of New Franchisors. Academy of Management Journal, 39(1), 216-234. 
The Franchise Handbook (2005). M.J.McDermott (Ed.), Milwaukee, WI: Enterprise Magazines, Inc.

Watson, A. (2006). Adoption of E-Business by UK franchise systems. Proceedings of the International Society of Franchising Conference, Palm Springs, CA.

Wood, J.V. (1989). Theory and Research Concerning Social Comparisons of Personal Attributes. Psychological Bulletin, 106(September), 231-248. 